\title{
EFFECT OF DIFFERENT CONCENTRATIONS OF TRIBULUS TERRESTRIS DRY EXTRACT ON HISTOLOGICAL STRUCTURE OF GONADS AND KIDNEYS IN JAPANESE QUAIL
}

\author{
Matina Nikolova $^{1}$, Georgi Penchev ${ }^{2}$, Svetlana Grigorova $^{3}$, Dimo Penkov ${ }^{1}$, \\ Hristo Hristev ${ }^{1}$, Iveta Koeva ${ }^{4}$ \\ ${ }^{1}$ Agricultural University, Blvd. Mendeleev 12, 4000 Plovdiv, Bulgaria \\ ${ }^{2}$ Trakia University, 6000 Stara Zagora, Bulgaria, \\ ${ }^{3}$ Institute of Animal Science, 2232 Kostinbrod, Bulgaria, \\ ${ }^{4}$ Medical University, Blvd. Vasil Aprilov 15-A, 4002 Plovdiv, Bulgaria \\ svet.grigorova@abv.bg
}

\begin{abstract}
This experiment was designed to evaluate the effect of different doses of Bulgarian product Vemoherb-T (dry extract of Tribulus terrestris) on egg production, serum level of testosterone and histological structure of gonads and kidneys in Japanese quail. In the experiment a total of 52 female and 16 male Japanese quail from Pharaon breed at the initial age of 44 days were involved. Quails were randomly divided in control and three experimental groups, 13 female and 4 male in each. Experimental groups received with the drink water the tested product in following daily doses: $4 \mathrm{mg} / \mathrm{kg}$ body weight (10 weeks); $10 \mathrm{mg} / \mathrm{kg}$ body weight (the first 5 weeks of the trial); $10 \mathrm{mg} / \mathrm{kg}$ body weight (10 weeks) for I $^{\text {st }}$, II $^{\text {nd }}$, III $^{\text {rd }}$ treated groups respectively. A significant increase of ovary weight in quails from III ${ }^{\text {rd }}$ experimental group $(\mathrm{P}<0.01)$ in comparison with the control was measured. Egg production in $\mathrm{II}^{\text {nd }}$ and $\mathrm{III}^{\text {rd }}$ treated groups increased significantly $(\mathrm{P}<0.01)$ than the control group. Testosterone level of males from III $^{\text {rd }}$ experimental group enhanced significantly $(\mathrm{P}<0.05 ; \mathrm{P}<0.01)$ than other groups. The ovary core part of females from III $^{\text {rd }}$ experimental group contained a much lower number of mature follicles in comparison to the other groups and its central medulla was highly vascularized. Tribulus terrestris extract in a dose of $10 \mathrm{mg} / \mathrm{kg}$ stimulates the production of male reproductive cells, while the dose of $4 \mathrm{mg} / \mathrm{kg}$ caused a delay of spermatozoa production. Histological analysis showed that in all experimental groups the structure of the kidneys was preserved and that the higher doses lead to certain reduction of the parenchyma.
\end{abstract}

Key words: Tribulus terrestris; Japanese quail; gonades and kidneys histological structure; testosterone level

\section{ЕФЕКТОТ НА РАЗЛИЧНИ КОНЦЕНТРАЦИИ СУВ ЕКСТРАКТ ОД TRIBULUS TERRESTRIS ВРЗ ХИСТОЛОШКАТА СТРУКТУРА НА ГОНАДИТЕ И БУБРЕЗИТЕ КАЈ ЈАПОНСКА ПОТПОЛОШКА}

\footnotetext{
Овој експеримент беше дизајниран за оценување на ефектот на различни дози од бугарскиот производ Vemoherb-T (сув екстракт од Tribulus terrestris) врз производството на јајца, нивото на тестостерон во серумот и хистолошката структура на гонадите и бубрезите кај јапонската потполошка. Во експериментот беа вклучени вкупно 52 женски и 16 машки јапонски потполошки од расата фараон со почетна возраст од 44 дена. Потполошките беа поделени во една контролна и три експериментални групи, 13 женски и 4 машки во секоја. Експерименталните групи тестираниот производ го примаа преку водата за пиење, и тоа во следните дози: $4 \mathrm{mg} / \mathrm{kg}$ телесна маса (10 недели); $10 \mathrm{mg} / \mathrm{kg}$ телесна маса (првите 5 недели од опитот); $10 \mathrm{mg} / \mathrm{kg}$ телесна маса (10 недели) за првата, втората и третата третирана група, соодветно. Сигнификантно зголемување на масата на јајчникот кај потполошките од третата експериментална група $(\mathrm{P}<0.01)$ беше измерено во споредба со контролната група. Производството на јајца во втората и третата третирана група се зголемило сигнификантно $(\mathrm{P}<0.01)$ во споредба со контролната група. Нивото на тестостерон кај мажјаците од третата експериментална група се зголемило сигнификантно $(\mathrm{P}<0.05 ; \mathrm{P}<0.01)$ во споредба со другите групи. Внатрешниот дел од јајчникот кај женките од третата експериментална група содржеше многу помал број зрели фоликули, во споредба со другите групи и централната медула беше високо васкуларизирана. Екстрактот од Tribulus terrestris во доза од $10 \mathrm{mg} / \mathrm{kg}$ го стимулира производството на машки репродуктивни
} 
клетки, додека дозата од $4 \mathrm{mg} / \mathrm{kg}$ предизвикува одолжување на времето за производство на сперматозоиди. Хистолошките анализи покажаа дека во сите експериментални групи структурата на бубрезите остана зачувана и дека високите дози доведоа до одредена редукција на паренхимот.

Клучни зборови: Tribulus terrestris; јапонска потполошка; хистолошка структура на гонади и бубрези; ниво на тестостерон.

\section{INTRODUCTION}

The annual herb Tribulus terrestris L. (Zygophyllaceae) has been used in the folk medicine ever since ancient times [1]. The extract of Tribulus terrestris (TT) has a positive effect on sexual desire and spermatogenesis in cocks [2] and on ovulation in Guinea fowls [3], as well as on cardiovascular diseases $[4,5]$. It reduces the cholesterol level in the blood serum [6], stimulates metabolism [7] etc. The dry extract of TT is a proven growth stimulator in rabbits [8]. The content of biologically active substances in TT depends on the geographical origin of the plant, on its vegetation stage, on the processing method [9]. According to the data of Kostova and Dinchev [10] TT samples collected from regions in Bulgaria and Moldova have a higher content of the furostanol saponin protodioscin, compared to herbal samples of other geographical regions.

Due to the many biologically active substances contained (including alkaloids), the continuous use of TT herbal extract and its application at higher doses, could cause overloading and destruction of some organs, such as liver [11] and gonads [12].

Studies in that area are quite limited. Few data were found in the available literature about the negative effect of different doses of the extract in humans and animals.

The aim of the present study was to establish the effect of different concentration of TT dry extract on egg productivity, testosterone level, histological structure of gonads and kidneys in Japanese quail (Coturnix coturnix japonica).

\section{MATERIAL AND METHODS}

In the current study dry extract of TT obtained by water-ethanol extraction was tested. The trademark of this product is Vemoherb T, produced from Bulgarian company "Vemo 99" Ltd., Sofia. It contains (in percent of dry matter): not less than $60 \%$ furostanol saponins defined as protodioscin; not less than $10 \%$ flavonoids determined as rutin; not less than $10 \%$ tannins. The product is harmless to humans and animals. Its heavy metals content is less than $0.001 \%$.
The experiment with 52 female and 16 male Japanese quails from Pharaon breed at the initial age of 44 days was conducted in the animal facilities of Department of Animal Sciences at the Agricultural University - Plovdiv, Bulgaria, in accordance with the Bulgarian Veterinary Low. Quails were randomly divided in control and three experimental groups, 13 female and 4 male in each. These were housed in stainless steel wire cages on a $16 \mathrm{~h}$ lighting schedule, air temperature of 21$24^{\circ} \mathrm{C}$ and relative humidity $70-85 \%$. The experiment lasted 11 weeks: one week preparatory and 10 weeks experimental period. Water was supplied via vacuum drinkers. All groups were fed the same diet for Japanese quails. Per kg diet contains: 11,8 MJ metabolizable energy, $180 \mathrm{~g}$ crude protein, $9 \mathrm{~g}$ lysine, $8 \mathrm{~g}$ methionine+cystine, $2.8 \mathrm{~g} \mathrm{Ca}$ and $0.43 \mathrm{~g}$ P. Experimental groups received with the drink water the tested product in following daily doses: 4 $\mathrm{mg} / \mathrm{kg}$ body weight (10 weeks); $10 \mathrm{mg} / \mathrm{kg}$ body weight (the first 5 weeks of the trial); $10 \mathrm{mg} / \mathrm{kg}$ body weight ( 10 weeks) for $\mathrm{I}^{\text {st }}, \mathrm{II}^{\text {nd }}, \mathrm{III}^{\text {rd }}$ treated groups respectively.

At the end of the experiment quails were humanely killed in accordance with Directive 2010/ $6_{3} / \mathrm{EC}$ of the European Parliament [13]. Before slaughtering, blood samples for testosterone determination were taken from vena jugularis after anesthesia with ethyl ether of males. The testes and ovaries weight was measured using OHAUS scales with a precision of $0,01 \mathrm{~g}$. For histological examination quail's gonads and kidneys were taken after slaughter and immediately were placed in Bouin's fixative for 24 hours. Then these organs were dehydrated for 48 hours in ascending alcohol series and embedded in paraffin blocks. Serial sections of 5-7 $\mu \mathrm{m}$ thickness were cut by using a microtome type Reichert, mounted on glass slides for hematoxylin-eosin staining by routine method. Digital images of the histological stained sections were captured with a CANON (Japan, 2005) digital camera mounted on a HUND microscope (Germany,2005) and stored as high quality jpg files.

Results were statistically analyzed using software product Excel 7 for Windows. The statistically significant difference between the control and experimental groups was determined using Student's t-test. 


\section{RESULTS AND DISCUSSION}

Gonad's weight, egg production and testosterone level in males' blood serum are shown in Table 1.

The ovary weight of quails from $\mathrm{III}^{\mathrm{rd}}$ experimental group increased significantly $(\mathrm{P}<0.01)$ than control group. However there were no significant differences concerning testes weight between control and experimental groups $(\mathrm{P}>0.05)$.

Significant higher egg production in II $^{\text {nd }}$ and $\mathrm{III}^{\text {rd }}$ experimental groups $(\mathrm{P}<0.01)$ compared to control and $\mathrm{I}^{\text {st }}$ experimental groups was established. Analogical results reported Nikolova et al. [3] in Guinea fowl given $10 \mathrm{mg} / \mathrm{kg}$ body weight/day Vemoherb T for a period of 12 weeks. Surdjiiska et al. [14] observed a tendency to in- crease the laying intensity in hens fed diet supplemented with TT in dose $10 \mathrm{mg} / \mathrm{kg}$ body weight/day for three weeks. The increase of egg production could be explained by the mechanism of action of furostanol saponins in TT extract (mainly protodioscin) which improve vital status and affecting on the hypothalamic-pituitary gonadal axis, influence on ovarian function [7]. A significant increase $(\mathrm{P}<0.01)$ of testosterone level in males from III $^{\text {rd }}$ experimental group compared to other groups was observed. Kashamov [15] reported similar results in cocks received with a diet $10 \mathrm{mg} / \mathrm{kg}$ body weight/day TT dry extract. The testosterone enhancement in the treated quails might be explained with the fact, that protodioscin in Tribulus increases the level of Luteinizing hormone (LH), which in its turn stimulates testosterone secretion [16].

\section{Table 1}

Weight of gonads, laying intensity and testosterone level of Japanese quails, treated with different doses of TT extract (mean $\pm S E$ )

\begin{tabular}{|c|c|c|c|c|}
\hline \multirow[t]{2}{*}{ Indices } & Control & I & II & III \\
\hline & \multicolumn{4}{|c|}{$n=13+/ 4 \overbrace{}^{\prime}$} \\
\hline Testes' weight, g dexter & $4.36 \pm 0.33$ & $3.63 \pm 0.23$ & $3.25 \pm 0.50$ & $4.02 \pm 0.17$ \\
\hline sinister & $3.70 \pm 0.24$ & $2.98 \pm 0.52$ & $3.95 \pm 0.42$ & $4.20 \pm 0.38$ \\
\hline Ovary weight, $g$ & $2.89 \pm 1.62 \mathrm{a}_{1}$ & $8.75 \pm 2.30$ & $8.09 \pm 1.99$ & $9.07 \pm 1.26 \mathrm{a}_{1}$ \\
\hline Egg production, \% & $70.64 \pm 3.63 \mathrm{a}_{2} \mathrm{a}_{3}$ & $71.62 \pm 3.08 \mathrm{a}_{4} \mathrm{a}_{5}$ & $81.46 \pm 2.27 \mathrm{a}_{2} \mathrm{a}_{4}$ & $82.47 \pm 2.64 \mathrm{a}_{3} \mathrm{a}_{5}$ \\
\hline Testosteron, ng/ml & $0.41 \pm 0.05 \mathrm{a}_{6}$ & $0.42 \pm 0.02 \mathrm{a}_{7}$ & $0.40 \pm 0.06 \mathrm{~b}$ & $0.66 \pm 0.03 \mathrm{a}_{6} \mathrm{a}_{7} \mathrm{~b}$ \\
\hline
\end{tabular}

Significant in each row: $\mathrm{a}_{(1,2,3,4,5,6,7)}-\mathrm{p}<0.01 ; \mathrm{b}-\mathrm{p}<0.05$

The gonads of poultry from control group had normal histological structure (Figs. 1 and 2). As well, no morphological abnormalities were noticed in Sertoli cells and in germ cells at any step of their development from spermatogonia to spermatids. By light microscopy, the lumens of the efferent ducts were full of a large number of spermatozoids.

In the ovaries, light microscopy revealed the presence all ovarian follicles. Follicles type primordial and primary occupied superficial regions within the ovarian cortex while the remaining follicles had a deeper location.

The structure of the testes in all experimental groups was represented by various histological pictures to Fig. 3. Within some samples, small number of mature or elongated spermatids to- gether with abundant presence of round spermatids and other spermatogenic cells were seen. In some cases in the birds from the first experimental group, only spermatogonia and Sertoli cells were found within the seminiferous epithelium. However, in the vast majority of the cases a combination of the above-mentioned histological pictures could be recorded, which is known as a changes of seminiferous tubules. Poultry from second group no displayed a variety of histological changes within the interstitial tissue, which accompanied minimal degrees of the change of seminiferous tubules. Frequently, the loose connective tissue of the interstitial compartment was densely packed with fibrocytes and Leydig cells together with small blood vessels (Fig. 3b). The testes of the third group were with normal histostructure. 

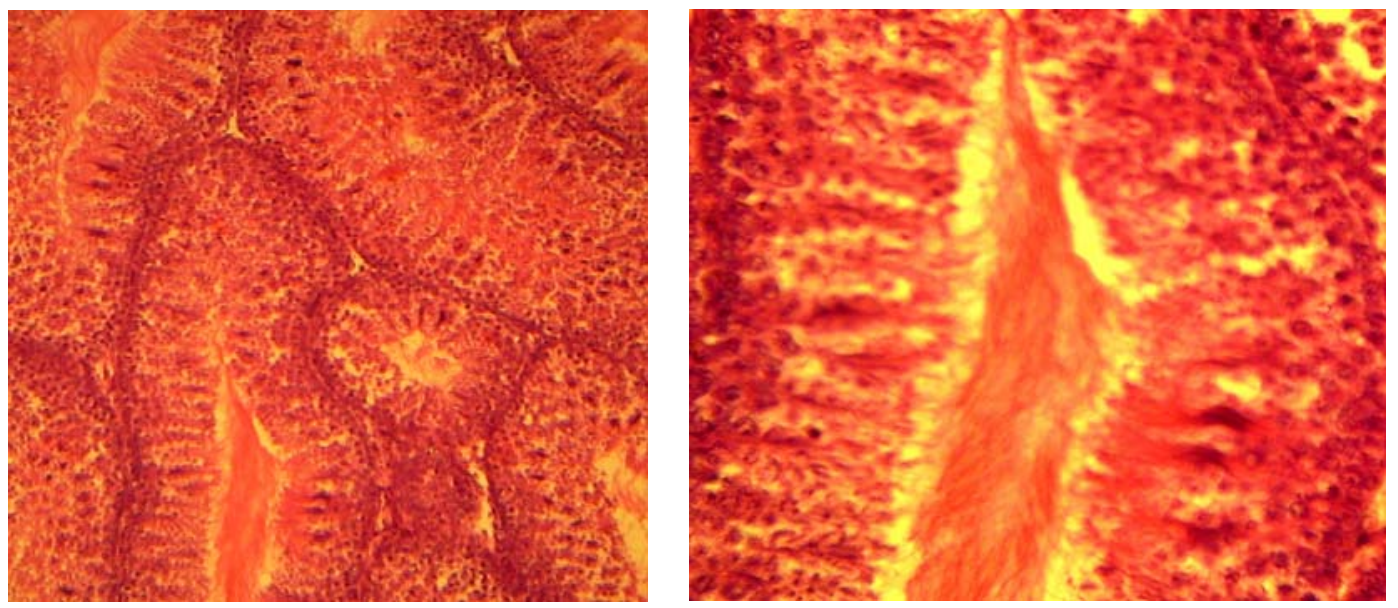

Fig. 1. Testis from the control group. Different generations of semen cells and lumen filled with spermatozoa

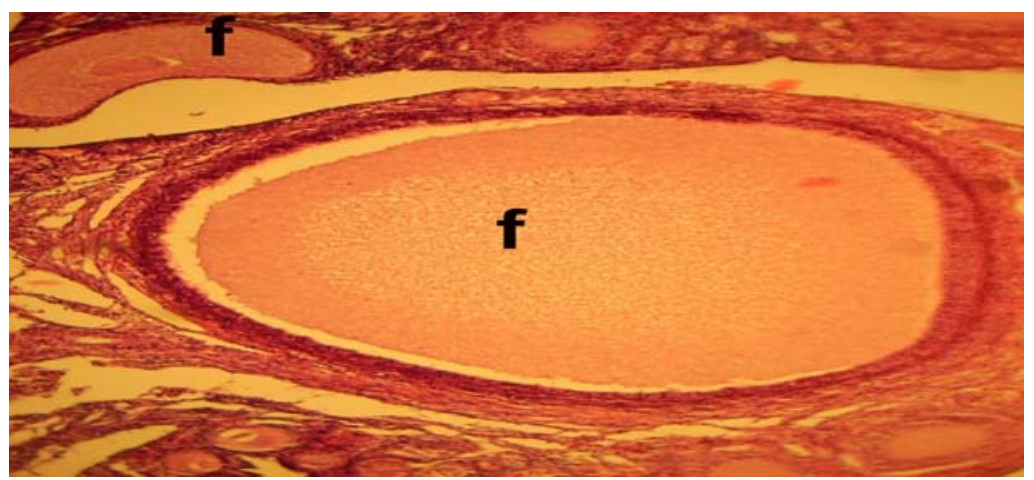

Fig. 2. Ovary from the control group. Cortex's zone filled with follicles in different stage of ripeness $f$ - follicles (secondary, tertiary, mature)

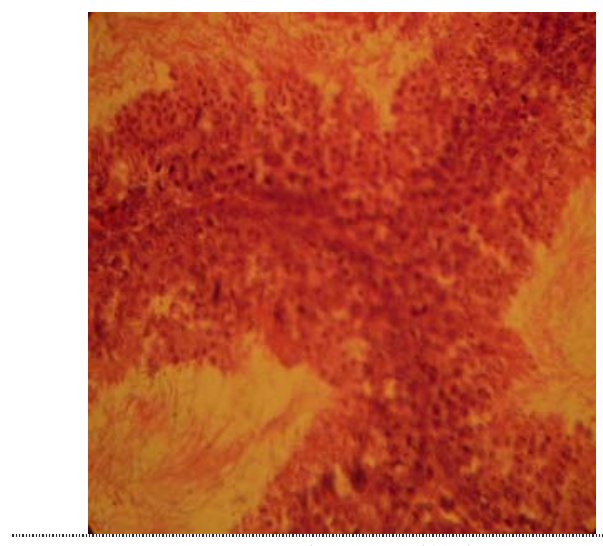

a) I group $(40 \times)$

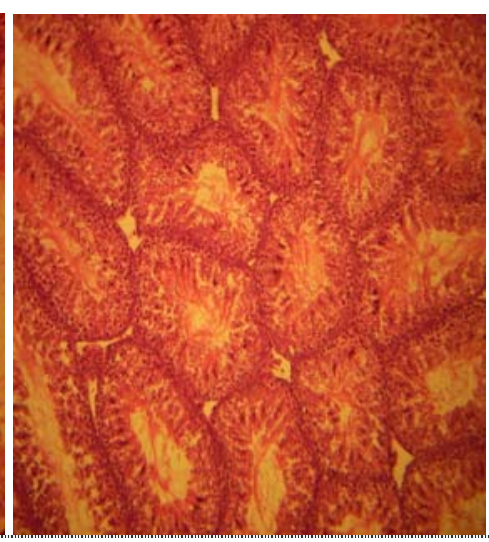

b) II group $(10 \times)$

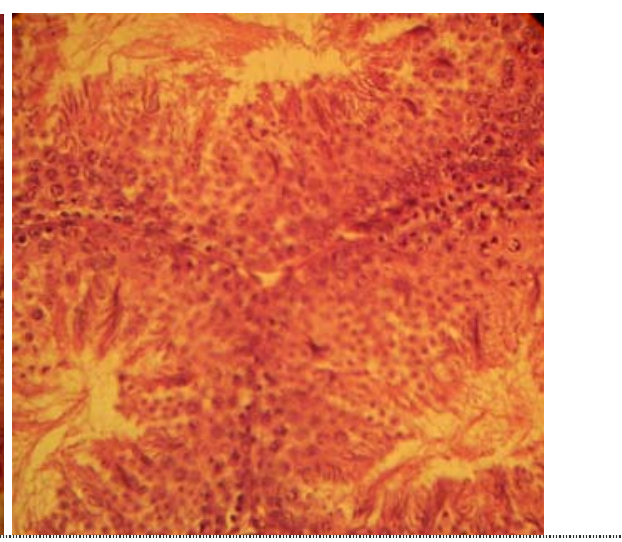

c) III group (40×)

Fig. 3. Testis from the experimented groups of quails. Twisted seminal channels with different generations of semen cells. The germinative epithelia and interstice are with preserved structure. By I-st group - data about decreased number of spermatozoa

Examination of ovarian sections of female quails from $\mathrm{I}^{\text {st }}$ and $\mathrm{II}^{\text {nd }}$ experimental groups, the cortical zone of the ovarian parenchyma was full of a large number of growing and mature follicles and yellow bodies, indicating for push up on ovulation. Well-developed graafian follicles were seen, surrounding by a fibrous theca externa.
The ovaries of the females from III $^{\text {rd }}$ group showed a reduction in the number of the primordial and the dominance follicles in comparison to other groups. No histological evidences of ovulation could be depicted in the ovarian sections. Neither a mature antral follicle nor a corpus luteum could be depicted, medullary part was highly vascularized. 
In an experiment with rabbits, treated with different daily doses of TT extract $(2.5,5,7.5$ and $10 \mathrm{mg} / \mathrm{kg}$ body weight) supplemented to drinking water for a period of 42 days, Abadjieva [17] and Abadjieva et al. [12] established the highest ovarian activity in animals received the lowest dose of the extract. The authors mentioned that increasing the dose (especially the daily treatment with 10 $\mathrm{mg} / \mathrm{kg}$ of live weight) led to follicular atresia, strongly expressed in the granulose cells of developing follicles (worsening the quality of oocytes). The possible reason for that is the initial increase of the exogenous levels of those hormones after supplementing the higher dose of the TT extract, in result of the protodioscin contained in it [18], reflecting following the principle of the negative feedback, by suppressing the release of the endogenous FSH and LH, causing atresia in its turn. Taking into account the observations reported by the above-mentioned authors and the similar results obtained in the present study, the dose of the TT extract should be carefully chosen when treating animals and birds reared for breeding purposes.

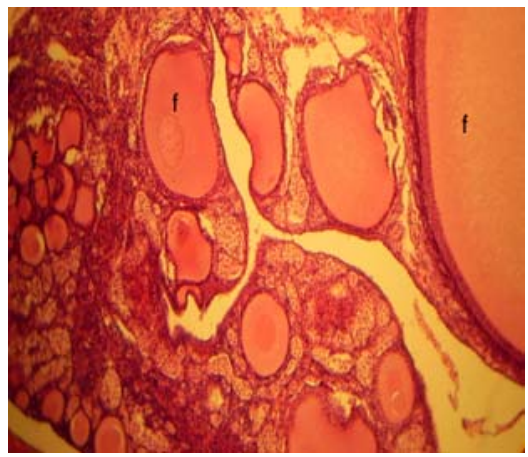

a) I group

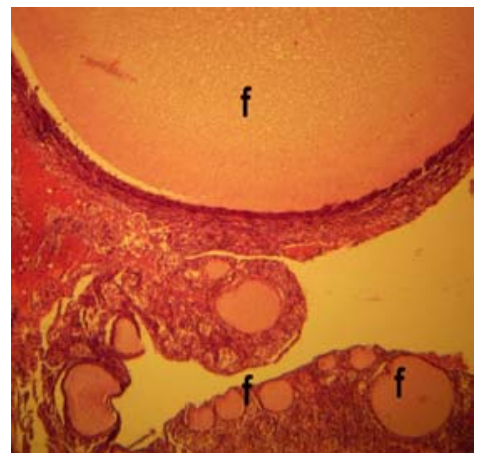

b) II group

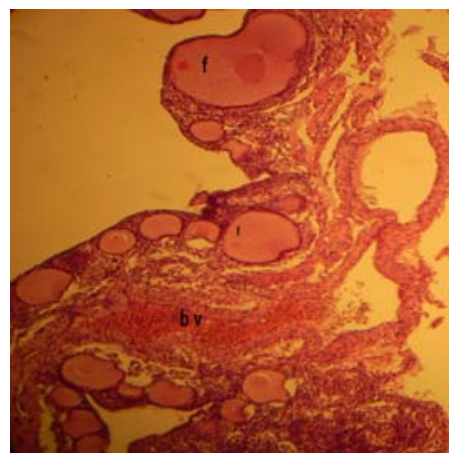

c) III group

Fig. 4. Ovaries from the experimented groups of quails. Cortex zone with many maturing and matured follicles and $c$ - luteum, $f$-follicles in different mature (preliminary, secondary, tertiary), $b v$ - blood vessels

The kidneys of the control quails had wellpreserved structure of the peripheral (cortical) and the internal (medullary) parts of the parenchyma and the nephron units located there (glomeruli, tubules and ducts) (Fig. 5). A certain renal parenchyma hypertrophy was established in the kidneys of poultry from the first group receiving $4 \mathrm{mg} / \mathrm{kg}$ of the additive; however the structure of the cortical and medullary parts remained well-preserved.
A reduction of the renal parenchyma was observed in the poultry from the second group (Fig. 6). In the third group the reduction of the cortical substance, especially of the medullary part, was even higher (Fig. 7). Histological analysis showed that in all experimental groups the structure of the kidneys was preserved and that the higher doses lead to certain reduction of the parenchyma.

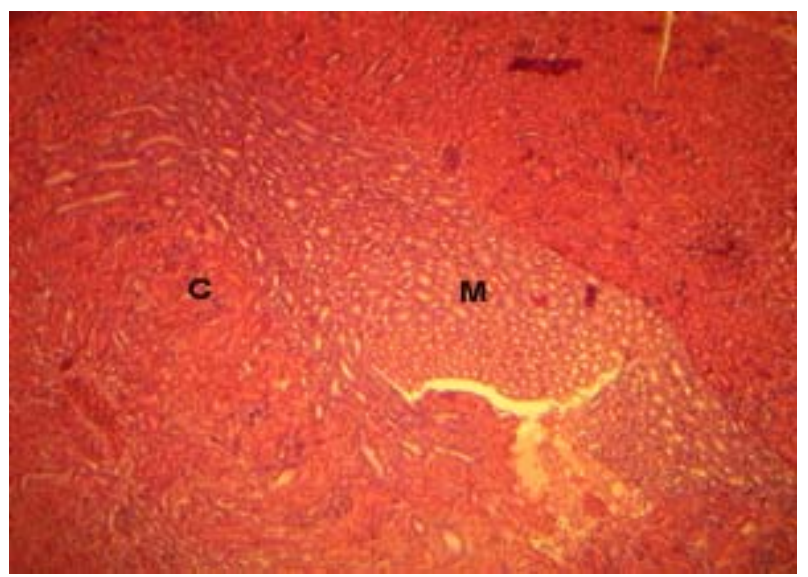

Fig. 5. Qual's kidney from control group 10×. Normal structure of cortex and medulla of the parenchyma, $\mathrm{C}$ - lobule-cortex, $\mathrm{M}$ - lobule-medulla 


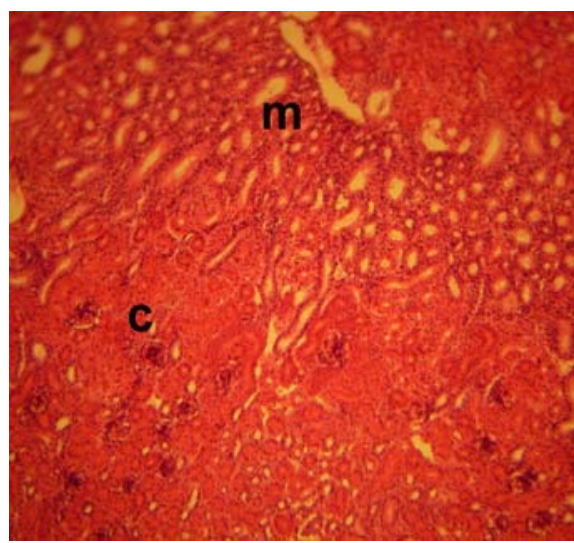

a) I group, 10×

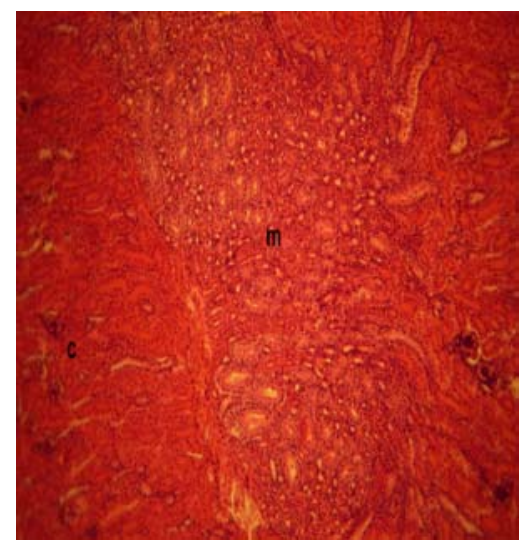

b) II group, $10 \times$

Fig. 6. Qails`s kidney from experimented groups. Partly reduction of the parenchyma, but preserved structure of cortex and medulla. $\mathrm{I}^{\mathrm{st}}$ group - renal parenchyma hypertrophy. $\mathrm{II}^{\text {nd }}$ group - partly reduction of the parenchyma. $m$ - core of partite, $c$ - cortex of partite

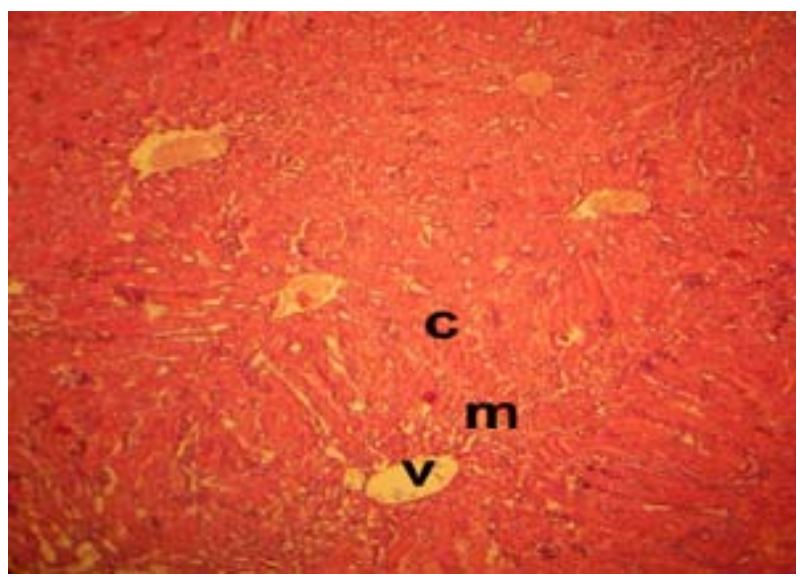

Fig. 7. Quail's kidney from III $^{\text {th }}$ experimental group. Reduction of the parenchyma - cortex, especially medulla-part, $v$ - vena, $m$ - core of partite, $c$ - cortex of partite

\section{CONCLUSIONS}

Under the conditions of the present study, a significant increase of ovary weight in quail from III $^{\mathrm{rd}}$ experimental group $(\mathrm{P}<0.01)$ in comparison with the control was measured.

Egg production in II $^{\text {nd }}$ and $\mathrm{III}^{\text {rd }}$ treated groups increased significantly $(\mathrm{P}<0.01)$ than the control group.

It was found significant enhancement of testosterone level in males from III experimental group ( $\mathrm{P}<0.05 ; \mathrm{P}<0.01)$ compared to control and to other experimental groups.

The cortical zone of ovarian parenchyma in female quails from $\mathrm{I}^{\text {st }}$ and $\mathrm{II}^{\text {nd }}$ experimental groups was full of a large number of growing and mature follicles and yellow bodies. The cortical part of ovary in females from III $^{\text {rd }}$ group contains a much smaller number of maturing and mature follicles than control group and to other groups. Its medullary part was highly vascularized.

Tribulus terrestris extract in a dose of 10 $\mathrm{mg} / \mathrm{kg}$ stimulates the production of male reproductive cells, while the dose of $4 \mathrm{mg} / \mathrm{kg}$ caused a delay of spermatozoa production.

Histological analysis showed that in all experimental groups the structure of the kidneys was preserved and that the higher doses lead to certain reduction of the parenchyma.

\section{REFERENCES}

[1] Adaikan, P. G., Gauthaman, K., Prasad, R. N., Ng, S. C.: Proerektile harmacological effects of Tribulus terrestris extract on the rabbit corpus cavernosum. Ann Acad Medicine, 29, 22-26 (2000).

[2] Grigorova, S., Kashamov B., Sredkova, B., Surdjiiska, S., Zlatev, H.: Effect of Tribulus terrestris extract on semen quality and serum total cholesterol content in White Ply- 
mouth Rock mini cocks. Biotechnol. Anim. Husb., 24, 139-146 (2008).

[3] Nikolova, M., Grigorova, S., Abadjieva, D., Penkov, D.: Investigation of the effect of Tribulus terrestris extract on some characteristics of the reproductive capacity of guinea fowl. Biotechnol. Anim. Husb., 26, 259-266 (2010).

[4] Sharifi A. M., Darabi, R., Akbarloo, N.: Study of antihypertensive mechanism of Tribulus terrestris in $2 \mathrm{~K} 1 \mathrm{C}$ hypertensive rats: Role of tissue ACE activity. Life Sci., 23, 2963-2971 (2003).

[5] Phillips, O. A., Mathew, K. T., Oriowo, M. A.: Antihypertensive and vasodilator effects of methanolic and aqueous extracts of Tribulus terrestris in rats. J. Ethnopharmacol., 104, 351-355 (2006).

[6] Grigorova S., Abadjieva, D., Nikolova, M., Penkov, D.: The effect of Tribulus terrestris extract on egg yolk lipids and serum cholesterol content in Guinea fowls. Biotechnol. Anim. Husb., 25, 1109-1115 (2009).

[7] Tomova, M.: Tribestan. Pharmacy, 37, 40-42 (1987).

[8] Valchev, G., Ivanov, A., Grigorova, S., Zlateva, N.: A study on the effect of Tribulus terrestris L. extract as a growth promoter for rabbits. J. Anim. Sci. (BG), 45, 96101 (2008).

[9] Ganzera, M., Bedir, E., Khan I. A.: Determination of steroidal saponins in Tribulus terrestris by reversed - phase high - performance liquid chromatography and evaporative light scattering detection. J. Pharm. Sci., 90, 17521758 (2001).

[10] Kostova, I.. Dinchev, D.: Saponins in Tribulus terrestris chemistry and bioactivity. Phytochemistry Reviews, 4, 111-137 (2005).

[11] Ivanova, R., Hristev, Hr., Penkov, D., Nikolova, M., Penchev, G., Grigorova, S.: Investigation the effect of dif- ferent concentrations of Tribulus terrestris dry extract on the status of the liver in quail (Coturnix coturnix japonica). Proceedings of the Jubilee Scientific Conference „Traditions and Challenges before Agricultural Education, Science and Business", Plovdiv, 14-17 October, 2010, LV (1), pp 253-258. (2010).

[12] Abadjieva, D., Grigorova, S., Valchev, G., Kistanova, E.: Ovarian structures in rabbits fed with additive Tribulus terrestris L. extract. J. Anim. Sci. (BG), 50, 82-88 (2013).

[13] http://www.europarl.europa.eu/sides/getDoc.do?pubRef= //EP//TEXT+REPORT+A7-20120216+0+DOC+XML+ $\mathrm{V} 0 / / \mathrm{BG}$.

[14] Surdjiiska, S., Stoyanov, D., Zlatev, Hr., Marinov, I., Marinov, Kr., Stankova, M.: Effect of application of Tribulus terrestris herbal extract (VemoHerb T) on the productivity in broiler breeders. Pticevadstvo, 5, 14-15 (2005).

[15] Kashamov, B.: Investigation the effects of supplementation of Tribulus terrestris L. in poultry. Dissertation, Sofia 2008.

[16] Kistanova, E., Zlatev, Hr., Karcheva, V., Kolev, A.: Effect of plant Tribulus terrestris extract on reproductive performance of rams. Biotechnol. Anim. Husb., 21, 55-63 (2005).

[17] Abadjieva, D.: Estimation of the Spirulina platensis and Vemoherb-T supplementation effect on the reproductive parameters of female rabbits, $\mathrm{PhD}$ Thesis, BAS - Sofia, (BG) (2015).

[18] Martino-Andrade, A. J., Morais, R. N., Spercoski, K. M., Rossi, S. C., Vechi , M. F., Golin, M., Lombardi, N. F., Greca, C. S., Dalsenter, P. R.: Effects of Tribulus terrestris on endocrine organs in male and female Wistar rate. Ethnopharmacol., 127, 165-171 (2010). 